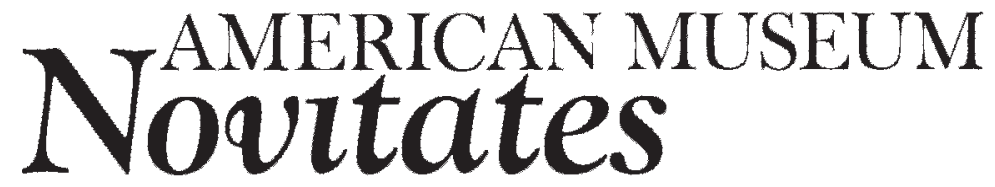

PUBLISHED BY THE AMERICAN MUSEUM OF NATURAL HISTORY CENTRAL PARK WEST AT 79TH STREET, NEW YORK, NY 10024 Number 3633, 9 pp., 5 figures, 1 table

December 31, 2008

\title{
Redescription of Mimoscorpius pugnator (Butler, 1872) (Arachnida: Thelyphonida), with first description of the female
}

\author{
JEREMY C. HUFF, ${ }^{1}$ CARLOS VÍQUEZ, ${ }^{2}$ AND LORENZO PRENDINI ${ }^{1}$
}

\begin{abstract}
A redescription of the endemic Guatemalan whip scorpion, Mimoscorpius pugnator (Butler, 1872), including the first description of the female, new records, and natural history observations, is provided.
\end{abstract}

\section{INTRODUCTION}

The whip scorpion (Thelyphonida) fauna of Central America is depauperate compared, for example, to the fauna of Southeast Asia. Prior to 2005, the order was represented in Central America by a single genus, Mastigoproctus Pocock, 1894, with three species. Three genera and five species are currently recognized (Armas and Víquez, 2005, 2007; Víquez and Armas, 2005, 2006a, 2006b). Mimoscorpius pugnator (Butler, 1872) is one of the most interesting. Originally described as a species of Thelyphonus Latreille, 1802, on the basis of a single adult male allegedly from the Philippines, the monotypic genus Mimoscorpius
Pocock, 1894 was later created to accommodate it. No further specimens were reported until more than 125 years after the original description, when a mature male was collected in southwestern Guatemala, and found to be conspecific with M. pugnator upon comparison with high-quality images of the holotype deposited in the Natural History Museum, London (Armas and Víquez, 2005, 2007; Víquez and Armas, 2006a). The type locality of $M$. pugnator was evidently erroneous and the species belongs to the Central American fauna (Armas and Víquez, 2005). This was a significant discovery because $M$. pugnator shares several morphological characters with Mastigoproctus, to which it appears closely related (Rowland and Cooke, 1973). This relationship is

\footnotetext{
${ }^{1}$ Division of Invertebrate Zoology, American Museum of Natural History, Central Park West at 79th Street, New York, 10024-5192, USA (jhuff@amnh.org and lorenzo@amnh.org).

2 Instituto Nacional de Biodiversidad, Santo Domingo, Heredia, P.O. Box 22-3100, Costa Rica (cvíquez@inbio.ac.cr).
} 
now more plausible based on the close geographical proximity of the two genera.

Mimoscorpius pugnator was recently found to be the senior synonym of Mastigoproctus liochirus Pocock, 1900, originally described from an immature male (Armas and Víquez, 2007). As a consequence of this synonymy, Central America is left without Mastigoproctus, which now have a disjunct distribution in North America, South America, and the Caribbean (Harvey, 2003; Armas and Víquez, 2007). It remains to be seen whether the Mastigoproctus species in South America and the Caribbean will remain in that genus.

In July 2006, two of the authors (J.C.H. and C.V.) traveled to Guatemala and collected several specimens of $M$. pugnator at different life stages, including the first adult female specimens of these sexually dimorphic whip scorpions. In the present contribution, we provide the first description of the female of $M$. pugnator, as well as new records and observations on the natural history of the species.

\section{MATERIAL AND METHODS}

The material examined is deposited in the following collections: AMNH (American Museum of Natural History, New York, USA); BMNH (The Natural History Museum, London, UK); IES (Instituto de Ecología y Sistemática, Havana, Cuba); INBio (Instituto Nacional de Biodiversidad, Heredia, Costa Rica); MUSHNAT (Museo de Historia Natural de la Universidad de San Carlos, Guatemala City, Guatemala); UVGC (Universidad del Valle de Guatemala, Guatemala City, Guatemala). Female genitalia were studied following methods described by Víquez and Armas (2005). Morphological terminology follows Millot (1949), except for pedipalp morphology which follows Snodgrass (1948). Measurements, taken with Mitutoyo ${ }^{\circledR}$ digital calipers and an ocular micrometer attached to an Olympus SZ60 dissection microscope, are recorded in millimeters. Digital images were obtained using a video camera attached to the same microscope, and prepared using "Montage Explorer" software (Syncroscopy Co., Cambridge, U.K.). Habitus photographs were taken using a Microptics ML-1000 digital imaging system.

\section{TAXONOMY}

\author{
Family Thelyphonidae Lucas, 1835
}

Subfamily Mastigoproctinae Speijer, 1933

Mimoscorpius Pocock, 1894

Mimoscorpius Pocock, 1894: 132; Kraepelin, 1897: 10, 1899: 206; Gravely, 1916: 62, 63, 71, 80, 83; Giltay, 1931: 24, 25; Mello-Leitão, 1931: 24; Werner, 1935; 467; Rowland, 1973: 6; Rowland and Cooke, 1973: 68; Harvey, 2003: 68; Armas and Víquez, 2005: 299-301, 2007: 507-509, figs. 1, 3; Víquez and Armas, 2006a: 299, 302-305, figs. 7, 13, 2006b: 37.

TyPe SPeCIEs: Thelyphonus pugnator Butler, 1872 , by original designation.

Diagnosis: Mimoscorpius differs from all other whip scorpions on the basis of the following combination of characters. Carapace with pair of well-developed anterolateral carinae, extending from lateral ocelli approximately two-thirds towards median ocular tubercle. Median ocelli not separated by superciliary carina. Three pairs of lateral ocelli. Abdominal tergites II and III divided, with median longitudinal suture; IV and often $\mathrm{V}$ with partial suture; $\mathrm{X}$ divided laterally by pleuron; XII (anal) with pair of large, oval, laterally compressed ommatoids. Flagellar segments each with flagellar organs, situated anteroventrally. Sternite II (o) with two inflated surfaces posterolaterally and posterior margin lobate medially. Seminal receptacle (q) tubular, kidney-shaped, posteriorly directed. Pedipalps ( $\delta$ ) with long, cylindrical femur, almost twice length of patella; patellar apophysis long, slender; tibia enlarged proximally, forming $\mathrm{ca} .45^{\circ}$ angle with longitudinal axis. Leg tibiae IV, each with single ventrodistal spur.

Mastigoproctus may be distinguished from Mimoscorpius on the basis of the following characters. The male pedipalp of Mimoscorpius is noticeably elongated, the trochanter dentition is not sexually dimorphic, and the tibia is almost as broad as long. The seminal receptacles of Mastigoproctus giganteus (Lucas, 1835), the type species of the genus, are short, vertically and posteriorly directed. The median ocelli of Mastigoproctus are separated by a well-developed superciliary carina. Leg tibiae II-IV each possess a single ventrodistal spur in $M$. giganteus. 


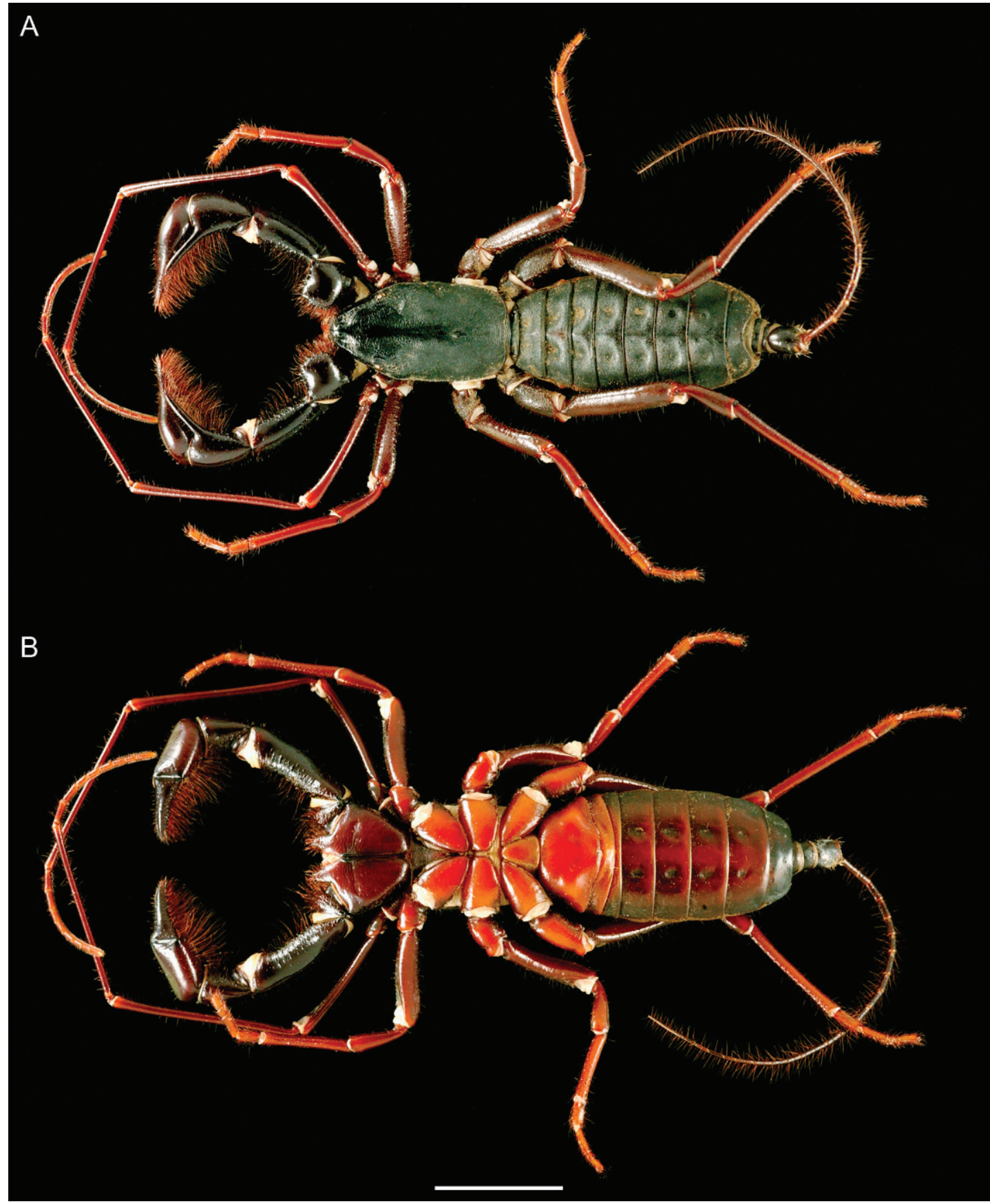

Fig. 1. Mimoscorpius pugnator (Butler, 1872), habitus, ô (AMNH). A. Dorsal aspect. B. Ventral aspect. Scale $=10 \mathrm{~mm}$. 


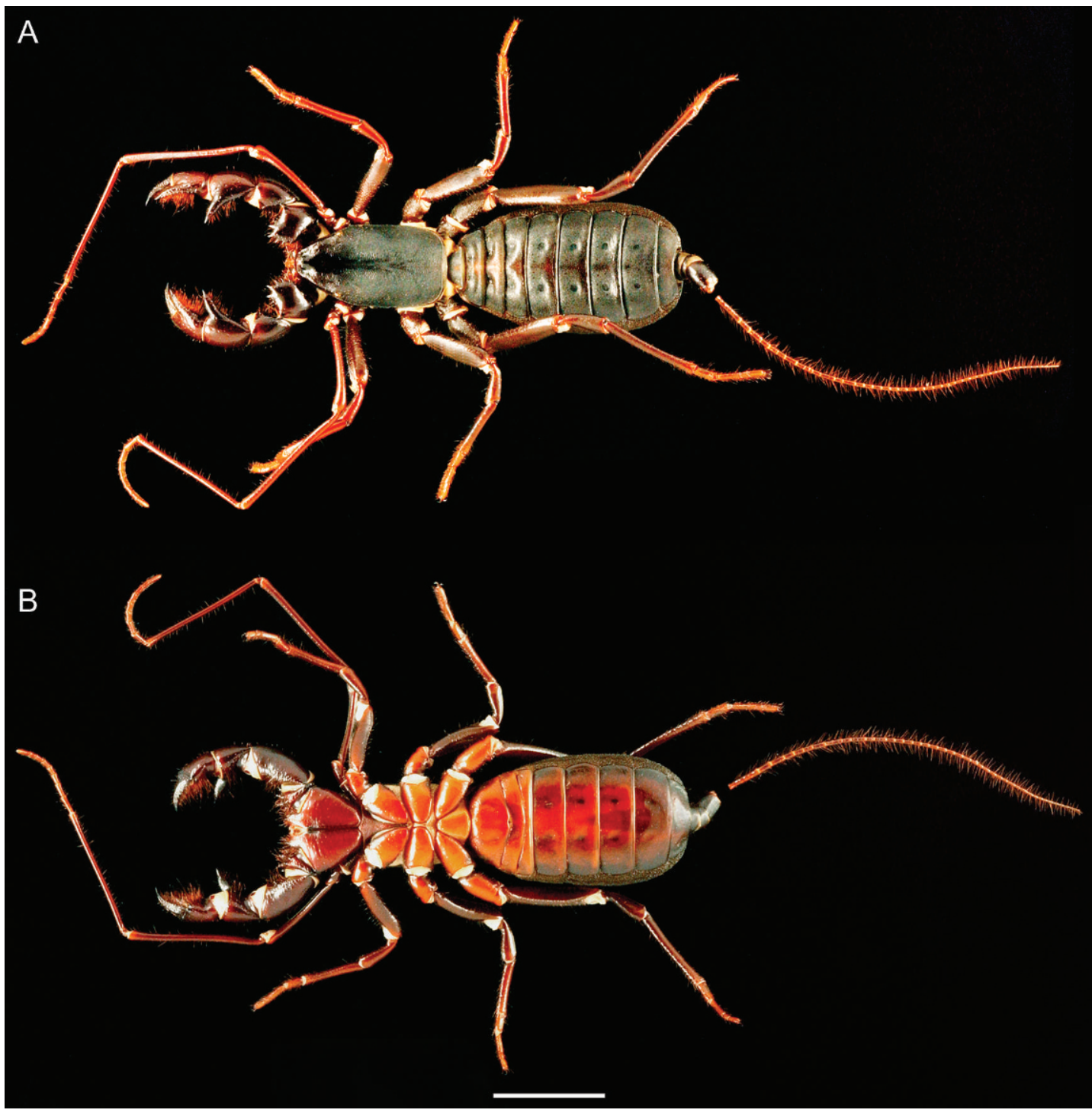

Fig. 2. Mimoscorpius pugnator (Butler, 1872), habitus, $q$ (AMNH). A. Dorsal aspect. B. Ventral aspect. Scale $=10 \mathrm{~mm}$.

Valeriophonus Víquez and Armas, 2005, a monotypic genus endemic to Costa Rica, differs from Mimoscorpius based on the presence of a stridulatory organ, situated on opposing surfaces of the pedipalp coxa and the basal cheliceral segment, and the presence, on leg tibiae III and IV, of a single ventrodistal spur in each case. Valeriophonus is further distinguished from Mimoscorpius on the basis of its relatively short, robust pedipalp with a well-developed lobe on the external surface of the fixed finger, and the short, vertically- and anteriorly-directed seminal receptacles.

DisTRIBUTION: This genus appears to be endemic to the Central American country of Guatemala.

\section{Mimoscorpius pugnator (Butler, 1872)}

Figures 1-11, table 1

Thelyphonus pugnator Butler, 1872: 204, pl. XIII, fig. 5 . 


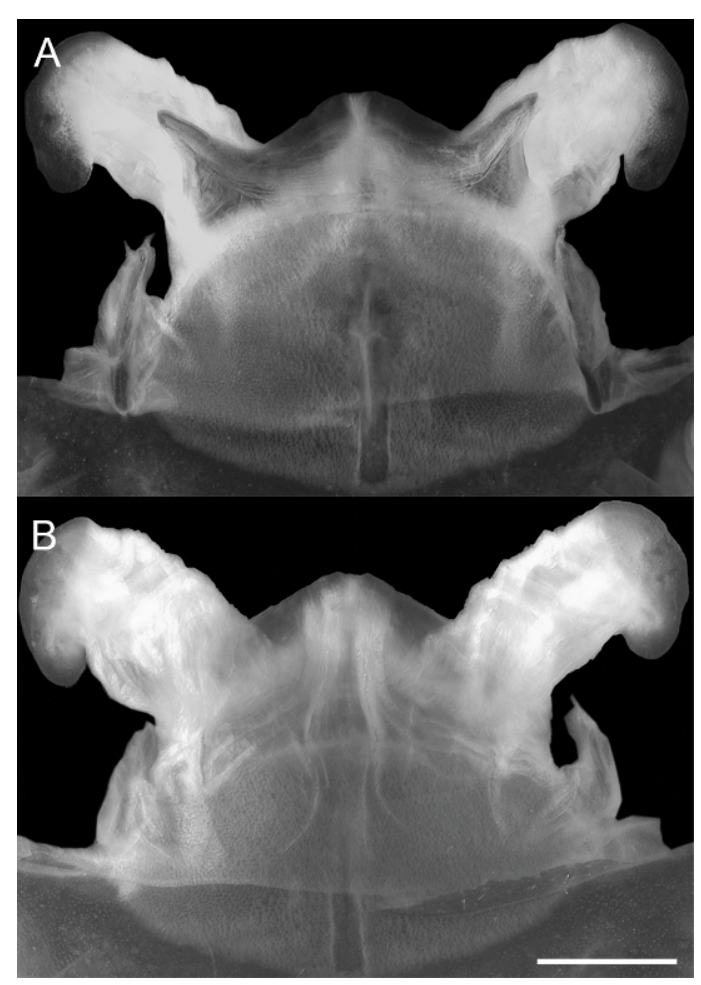

Fig. 3. Mimoscorpius pugnator (Butler, 1872), genitalia, $q$ (AMNH). A. Dorsal aspect. B. Ventral aspect. Scale $=3 \mathrm{~mm}$.

Mimoscorpius pugnator: Pocock, 1894: 132; Kraepelin, 1897: 40, 1899: 207; Gravely, 1916: 71; Giltay, 1931: 24, 25; Mello-Leitão, 1931: 24; Werner, 1935: 467, fig. 171; Rowland and Cooke, 1973: 64, 68; Rowland, 1973: 6, 7, 9; Harvey, 2003: 68; Armas and Víquez, 2005: 299-301, 2007: 507-509, figs. 1, 3; Víquez and Armas, 2006a: 302-305, figs. 7, 13, 2006b: 37.

Mastigoproctus liochirus Pocock, 1900: 299 (synonymized by Armas and Víquez, 2007: 507-509, fig. 2). Pocock, 1902: 46, 48, pl. X, fig. 5; Mello-Leitão, 1931: 26, 27, 29, fig. 13; Rowland and Cooke, 1973: 68; Valerio, 1981: 15-17, fig. 3; Vásquez Rojas, 1996: 69; Lazell, 2000: 306, 309; Armas and Maes, 2000: 14, 15; Rowland, 2002: 192; Harvey, 2003: 67; Víquez, 2003: 84, 85, map 1, fig. 1; Armas, 2004: 53; Víquez and Armas, 2006a: 299, 301-304, figs. 5, 13.

Holotype: 1 \& (BMNH), "Philippine Islands" (digital photomicrographs examined). For discussion on the type locality, see Armas and Víquez (2005).

Diagnosis: As for genus.

DEsCRIPTION: The following description is

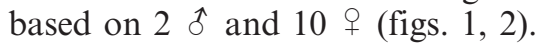

Total length: Maximum adult length measured from anterior margin of carapace to

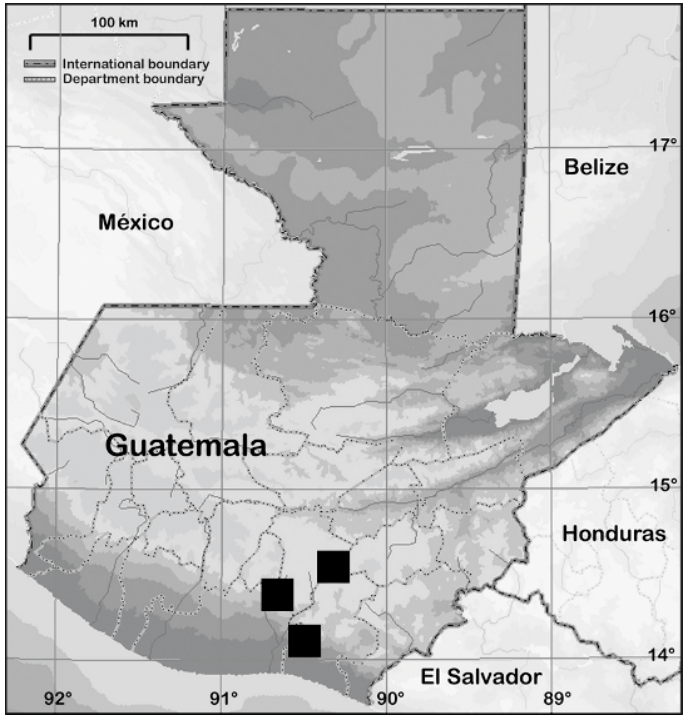

Fig. 4. Map of Guatemala, plotting the known locality records of Mimoscorpius pugnator (Butler, 1872).

posterior edge of pygidium (segment XII), $35.73 \mathrm{~mm}$ ( ठ̊), $38.03 \mathrm{~mm}$ (ㅇ) (table 1).

Color: Carapace, black. Opisthosoma, dorsal surface, black. Tergites II-IV, region of longitudinal suture, reddish-brown. Sternites I-VII, ventral surfaces, reddish-brown to light brown, lateral edges, dark brown; VIII, dark brown to black. Pygidium, dorsal and ventral surfaces, dark brown. Flagellum, dorsal, lateral and ventral surfaces, reddish-brown, covered with reddish setae. Pedipalp trochanter, dorsal and ventral surfaces, dark reddishbrown. Pedipalp femur, dorsal and ventral surfaces, dark brown. Pedipalp patella, tibia and basitarsus, dorsal and ventral surfaces, dark reddish-brown. Internal surface with numerous long, red setae. Leg I, all segments, reddish-brown; II-IV, coxa, ventral surface, light reddish-brown to orange-brown, trochanter and femur, dark reddish-brown, patella and tibia, reddish-brown, basitarsus and tarsus, light reddish-brown to orange-brown.

Carapace: Carapace with pair of welldeveloped anterolateral carinae, extending from lateral ocelli approximately two-thirds towards median ocular tubercle. Anterior surface and median ocular tubercle, smooth; remainder of carapace wrinkled, becoming densely and finely granular posteriorly, with 


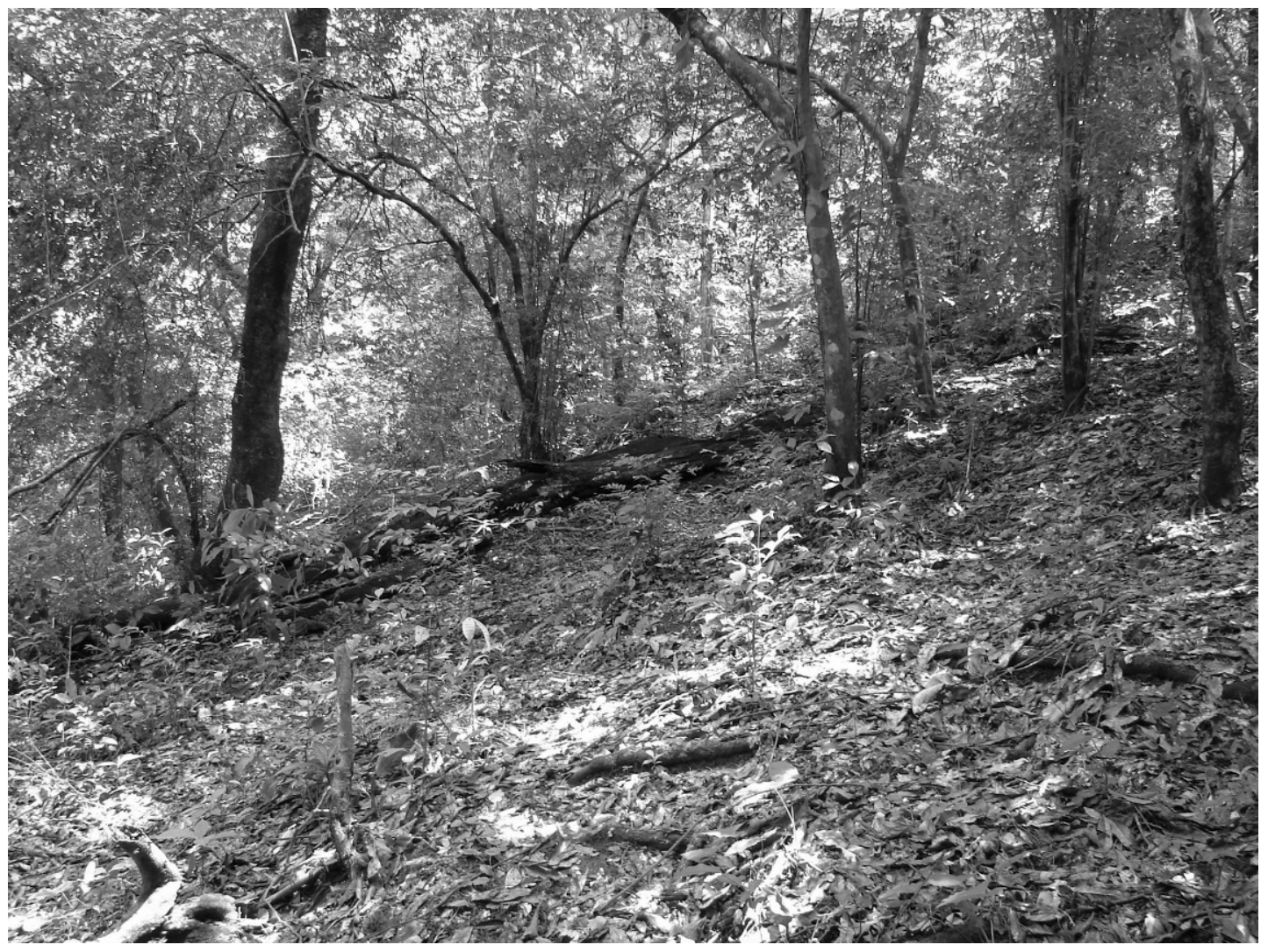

Fig. 5. Subtropical forest habitat of Mimoscorpius pugnator (Butler, 1872) near El Papayo, Guatemala.

sparse granules on lateral surfaces. Median ocular tubercle situated $0.74 \mathrm{~mm}$ from anterior margin of carapace (table 1); distance between ocelli 1.4 times ocular diameter. Posterior fovea obsolete; epistoma present, small. Three pairs of lateral ocelli: anterior ocellus nearly twice the diameter of median ocellus; posterior ocellus only slightly smaller than anterior ocellus; distance between posterior and median ocelli twice the distance between anterior and median ocelli.

Pedipalps: Cuticle very smooth, shiny, and sparsely punctate. Coxa, external and ventral surfaces smooth; apophysis with one tooth distally. Trochanter smooth, as wide as ( $\vec{\delta})$ or wider than ( + ) long; dorsointernal surface with six teeth, all similar in size, relatively small, proximal three pointed, distal three blunt, rounded $(\delta)$ or with teeth larger, increasing in size medially, all sharply pointed $(+)$; ventrointernal surface with two teeth.
Femur ( $\hat{\delta}$ ) almost cylindrical, twice length of trochanter; ventroexternal surface without teeth; ventrointernal surface with one small, blunt tooth medially. Femur ( $q$ ) not cylindrical, only slightly longer then trochanter; ventroexternal surface with one small tooth medially; ventrointernal surface with one larger, more pronounced tooth medially. Patella relatively short, smooth; dorsointernal surface with one short tooth $(+)$ or with vestigial tooth $(\hat{\delta})$, situated proximal to apophysis. Patellar apophysis very elongated, smooth and slender $(\delta)$ or unmodified ( $(+)$; internal edge with serrate row of denticles; external edge smooth. Tibia, external edge flattened $(\delta)$ or rounded $(+)$; internal surface with numerous long, red macrosetae $(\hat{\delta})$ or with fewer, shorter macrosetae $(+\circ)$; ventrointernal surface with one tooth distally. Fixed finger, dorsal edge smooth $(\hat{\sigma})$ or with serrate row of denticles $(+)$; ventral edge with serrate 
TABLE 1

Mimoscorpius pugnator (Butler, 1872), selected measurements (mm)

\begin{tabular}{|c|c|c|c|c|c|c|c|}
\hline & Sex & $\delta$ & $\delta$ & q & q & q & q \\
\hline & Locality & EP & EP & EP & EP & $\mathrm{EP}$ & $\mathrm{PB}$ \\
\hline & Collection & AMNH & InBio & $\mathrm{AMNH}$ & AMNH & $\mathrm{AMNH}$ & $\mathrm{AMNH}$ \\
\hline \multirow[t]{6}{*}{ Carapace } & Length & 13.53 & 15.20 & 12.94 & 13.29 & 13.68 & 12.91 \\
\hline & Width at lateral ocelli & 6.66 & 7.33 & 5.91 & 6.16 & 5.79 & 6.05 \\
\hline & Width at fovea & 7.34 & 9.01 & 7.07 & 7.24 & 7.12 & 7.73 \\
\hline & Median ocular tubercle distance ${ }^{1}$ & 0.75 & 0.92 & 0.68 & 0.69 & 0.68 & 0.69 \\
\hline & Ocular width & 0.47 & 0.50 & 0.36 & 0.39 & 0.39 & 0.30 \\
\hline & Distance between median ocelli & 0.63 & 0.70 & 0.54 & 0.55 & 0.45 & 0.49 \\
\hline \multirow[t]{6}{*}{ Leg I } & Coxa length & 2.59 & 3.48 & 2.75 & 2.62 & 2.67 & 2.58 \\
\hline & Trochanter length & 2.29 & 2.84 & 2.23 & 2.22 & 2.24 & 2.24 \\
\hline & Femur length & 9.57 & 11.46 & 8.51 & 8.37 & 8.40 & 8.60 \\
\hline & Patella length & 14.19 & 16.67 & 12.32 & 11.85 & 12.07 & 11.80 \\
\hline & Tibia length & 13.13 & 15.86 & 11.56 & 11.50 & 11.20 & 11.58 \\
\hline & Basitarsus-tarsus length & 9.30 & 11.52 & 8.08 & 8.28 & 8.01 & 7.31 \\
\hline \multirow[t]{7}{*}{ Leg IV } & Coxa length & 4.12 & 5.12 & 4.19 & 3.82 & 3.93 & 4.18 \\
\hline & Trochanter length & 4.32 & 5.46 & 4.87 & 4.67 & 4.39 & 4.81 \\
\hline & Femur length & 10.47 & 11.69 & 9.10 & 8.63 & 9.68 & 10.20 \\
\hline & Patella length & 4.75 & 5.60 & 4.58 & 4.04 & 4.26 & 4.50 \\
\hline & Tibia length & 9.41 & 11.45 & 8.93 & 8.38 & 8.38 & 8.67 \\
\hline & Basitarsus length & 3.01 & 2.60 & 2.12 & 1.91 & 2.00 & 2.37 \\
\hline & Tarsus length & 4.62 & 5.10 & 4.61 & 4.34 & 4.02 & 3.95 \\
\hline Total length $^{2}$ & & 36.69 & 46.00 & 36.82 & 38.53 & 38.19 & 34.15 \\
\hline
\end{tabular}

${ }^{1}$ Measured from anterior carapace margin.

${ }^{2}$ Measured from anterior carapace margin to posterior edge of pygidium.

Abbreviations: AMNH (American Museum of Natural History, New York); EP (El Papayo, Guatemala); PB (Peña Blanca, Guatemala); InBio (Instituto Nacional de Biodiversidad, Santo Domingo, Costa Rica).

row of denticles; strongly curved downwards, overlapping basitarsus ( $\delta$ ) or straight, not overlapping basitarsus ( + ). Basitarsus, dorsal edge with serrate row of denticles; ventral edge smooth $(\delta)$ or with serrate row of denticles ( + ); apex bifid $(\hat{\theta})$.

Legs: Leg I, basitarsus and telotarsus, tarsomeres I-VII gradually decreasing in size, with I largest; tarsomere VIII almost as long as I. Legs II-IV, basitarsus with two ventrodistal spurs. Leg IV, tibia with one ventrodistal spur.

Trichobothria: Leg I with two trichobothria; other legs with one trichobothrium; present at distal end of leg tibiae only.

Opisthosoma: Abdominal tergites finely granular; II and III divided by median longitudinal suture; IV and often V, suture reaching approximately to anterior third of segment; X divided laterally by suture (pleuron); XII with pair of large, laterally compressed oval ommatoids. Sternite II (genital)
( $₫$ ) with pair of inflated surfaces posterolaterally; posterior margin with conspicuous, subrectangular median lobe; III and IV undivided, III three times longer than IV; remaining sternites smooth medially, finely punctate laterally. Sternite II (genital) (q) unmodified; posterior margin with small median notch, small circular sclerotized structure below surface of cuticle posterior to median notch. Seminal receptacles tubular, kidney-shaped, convex dorsally, concave ventrally; posteriorly directed (fig. 3).

Sexual dimorphism: The adult male exhibits several secondary sexual characters not observed in the adult female. The pedipalps of the male are elongated, with a modified tibia, compared to the female in which the pedipalps are relatively short and robust, with an unmodified tibia. Sternite II presents two inflated surfaces posterolaterally, and its posterior margin is lobate medially, in the male, but is unmodified in the female. 
Material Examined: GUATEMALA: $D e$ partamento Escuintla: San Vicente, Pacaya, Los Almendros farm $\left(14^{\circ} 24^{\prime} 58^{\prime \prime} \mathrm{N} 90^{\circ} 38^{\prime} 21^{\prime \prime} \mathrm{W}\right)$, 3.v.2001, F. Alvarado, 1 (UVGC). Departamento Guatemala: Peña Blanca $\left(14^{\circ} 32^{\prime} 0^{\prime \prime} \mathrm{N}\right.$ $\left.90^{\circ} 20^{\prime} 0^{\prime \prime} \mathrm{W}\right)$, 3.vii.1980, T. Okazawa, 1 + (AMNH). Departamento Santa Rosa: Taxisco, El Papayo village $\left(14^{\circ} 08^{\prime} 03^{\prime \prime} \mathrm{N} 90^{\circ} 33^{\prime} 52^{\prime \prime} \mathrm{W}\right)$, 270 m, 13.vi.2002, C. Ávila Ramos, 1 శ (INBio); same locality, 3-4.vii.2006, C. Víquez, J. Huff, D. Ortiz, C. Ávila, and R. Estrada, 1 \%, 3 q, 9 juv. (AMNH), 2 +, 1 juv. $\delta, 1$ juv. + (INBio), 2 +, 1 juv. $\delta$ (MUSHNAT), 1 +1 juv. $\hat{s}, 1$ juv. + (IES).

Distribution: Recorded from the Escuintla, Guatemala and Santa Rosa departments of Guatemala (fig. 4).

Natural History: Mimoscorpius pugnator inhabits humid subtropical forests at an elevation of $270 \mathrm{~m}$, with a temperature of 18 $24^{\circ} \mathrm{C}$, and mean annual precipitation of 1000 $2000 \mathrm{~mm}$ (fig. 5). This species was collected in small mammal (agouti or armadillo) burrows, holes at the base of large trees, and from inside and under rotten logs. Six $M$. pugnator specimens were taken, together with several schizomids, from an agouti burrow which contained many dead leaves. These whip scorpions appear to tolerate each other when in close proximity and no aggression was observed among individuals of various sizes. The defensive spray of this species smells strongly of acetic acid.

\section{ACKNOWLEDGMENTS}

We are indebted to Sergio Pérez (MUSHNAT) and Enio Cano (UVGC) for helping J.H. and C.V. during the expedition to Guatemala (2006) and for the initial loan of Mimoscorpius to C.V. We thank Emmanuel Agreda, David Ortiz, and Carlos Ávila for invaluable assistance in the field and in obtaining collecting and export permits for the expedition. Ricardo Estrada assisted as guide and collector in El Papayo. We thank Janet and George Beccaloni (BMNH) for providing photos of the holotype of $M$. pugnator, Steve Thurston for assistance with preparing the plates, and James Cokendolpher and Mark Harvey for critical review of the manuscript. The expedition to Guatemala was funded by U.S. National Science Foundation grant EAR 0228699 to L.P.

\section{REFERENCES}

Armas, L.F. de. 2004. Arácnidos de República Dominicana: Palpigradi, Schizomida, Solifugae y Thelyphonida (Chelicerata: Arachnida). Revista Ibérica de Aracnología Volumen Especial Monográfico 2: 1-63.

Armas, L.F. de., and J.M. Maes. 1999. Uropygi, un orden de Arachnida (Chelicerata) nuevo para Nicaragua. Revista Nicaraguense de Entomologia 50: $13-15$.

Armas, L.F. de., and C. Víquez. 2005. ¿Es Mimoscorpius un taxón asiático o centroamericano? (Thelyphonida: Thelyphonidae). Boletín de la Sociedad Entomológica Aragonesa 37: 299-301.

Armas, L.F. de., and C. Víquez. 2007. Mastigoproctus liochirus Pocock, 1900 is a junior synonym of Mimoscorpius pugnator (Butler, 1872) (Arachnida: Thelyphonida). Boletín de la Sociedad Entomológica Aragonesa 40: 507-509.

Butler, A.G. 1872. A monograph of the genus Thelyphonus. Annals and Magazine of Natural History (4) 10: 200-206.

Giltay, L. 1931. Scorpions et Pédipalpes. In Résultants scientifiques du voyage aux Indes Orientales Néerlandaises de LL. AA. RR. De Prince et la Princesse Léopold de Belgique. Mémoires du Musée Royal d'Histoire Naturelle de Belgique 3: 1-28.

Gravely, F.H. 1916. The evolution and distribution of the Indo-Australian Thelyphonidae, with notes on the distinctive characters of various species. Records of the Indian Museum 12: 59-85.

Harvey, M.S. 2003. Uropygi. In Catalogue of the Smaller Arachnid Orders of the World: Amblypygi, Uropygi, Schizomida, Palpigradi, Ricinulei and Solifugae. Canberra: CSIRO Publishing, 59-99.

Kraepelin, K. 1897. Revision der Uropygi Thor. (Thelyphonidae auct.). Abhandlungen aus dem Gebiete der Naturwissenschaften herausgegeben vom Naturwissenschaftlichen Verein in Hamburg 15: 1-58.

Kraepelin, K. 1899. Scorpiones und Pedipalpi. In Das Tierreich, 8, Berlin: R. Friedländer, 201233.

Lazell, J. 2000. Mastigoproctus transoceanicus sp. nov. (Arachnida: Uropygida: Thelyphonidae), a genus new to the Old World, with discussion of the biogeography of the order. Acta Zootaxonomica Sinica 25: 304-311. 
Mello-Leitão, C. de. 1931. Pedipalpos do Brasil e algumas notas sobre a Ordem. Arquivos do Museu Nacional Rio de Janeiro 33: 7-72, 3 pl.

Millot, J. 1949. Ordres des Uropyges. In P.P. Grassé (editor), Traité de Zoologie, 6, Paris: Masson et Cie, 533-562.

Pocock, R.I. 1894. Notes on the Thelyphonidae contained in the collection of the British Museum. Annals and Magazine of Natural History (6) 14: 120-134.

Pocock, R.I. 1900. Some new or little-known Thelyphonidae and Solifugae. Annals and Magazine of Natural History (7) 5: 294-306.

Pocock, R.I. 1902. Arachnida: Scorpiones, Pedipalpi, and Solifugae. In F.D. Godman and O. Salvin (editors), Biologia Centrali-Americana, 3, London: Taylor and Francis, 45-48, pl. 10.

Rowland, J.M. 1973. Uropygida (Arachnida) of the Philippine Islands, with description of a new genus and species. Occasional Papers of the Museum, Texas Tech University 16: 1-11.

Rowland, J.M. 2002. Review of the South American whip scorpions (Thelyphonida: Arachnida). Amazoniana 17: 187-204.

Rowland, J.M., and J.A.L. Cooke. 1973. Systematics of the arachnid order Uropygi (= Thelyphonida). Journal of Arachnology 1: 55-71.

Snodgrass, R.E. 1948. The feeding organs of Arachnida, including mites and ticks. Smithsonian Miscellaneous Collections 110: 26-31.

Valerio, C.E. 1981. A new species of Mastigoproctus (Thelyphonidae), the first record of
Uropygida from Costa Rica. Bulletin of the American Museum of Natural History 170(1): $15-17$.

Vázquez-Rojas, I. 1996. Uropygi. In J.E. Llorente Bousquets, A.N. García Alderete and E. González Sorano (editors), Biodiversidad, taxonomía y biogeografía de artrópodos de México: hacia una síntesis de su conocimiento. Mexico City: Universidad Nacional Autónoma de Mexico, 67-69.

Víquez, C. 2003. Whip scorpios [sic] of Central America. Sklípkan 8: 84-86.

Víquez, C., and L.F. de Armas. 2005. Dos nuevos géneros de vinagrillos de Centroamérica y las Antillas (Arachnida: Thelyphonida). Boletín de la Sociedad Entomológica Aragonesa 37: 95-98.

Víquez, C., and L.F. de Armas. 2006a. Los vinagrones de Guatemala (Arachnida: Thelyphonida). In E.B. Cano (editor), Biodiversidad de Guatemala, 1, Guatemala City: Universidad del Valle de Guatemala, 299-306.

Víquez, C., and L.F. de Armas. 2006b. Un nuevo género y dos nuevas especies de vinagrillos centroamericanos (Arachnida: Thelyphonida). Boletín de la Sociedad Entomológica Aragonesa 38: 37-41.

Werner, F. 1935. Klasse: Arachnoidea, Spinnentiere, Pedipalpen. In H.G. Bronn (editor), Klassen und Ordnungen des Tierreichs, 5 (IV) (8) (3): 317-490. Leipzig: Akademische Verlagsgesellschaft. 


Complete lists of all issues of the Novitates and the Bulletin are available at World Wide Web site http://library.amnh.org/pubs. Inquire about ordering printed copies via e-mail from scipubs@amnh.org or via standard mail from: American Museum of Natural History, Library-Scientific Publications, Central Park West at 79th St., New York, NY 10024. TEL: (212) 769-5545. FAX: (212) 769-5009.

(2) This paper meets the requirements of ANSI/NISO Z39.48-1992 (Permanence of Paper). 